\title{
Improving Verbal Linguistic Intelligence in Early Childhood Through the Use of Tiktok Media
}

\author{
Agus Nu'man', Indriana Rahmawati ${ }^{2}$, Ahmad Zubaidi', Ainul Yatin ${ }^{4}$, Hasti Retno Dewi ${ }^{4}$ \\ Pendidikan Bahasa Arab, Sekolah Tinggi Agama Islam Nurul Huda Kapongan Situbondo, \\ Indonesia (1); Pendidikan Agama Islam, Universitas Islam Negeri Sultan Aji Muhammad \\ Idris, samarinda (2); Pendidikan Agama Islam, Universitas Nurul Jadid, Paiton, Probolinggo(3) \\ Pendidikan Islam Anak Usia Dini, Universitas Nurul Jadid, Paiton, Probolinggo( ${ }^{(4)}$ \\ DOI: $\underline{10.31004 / o b s e s i . v 6 i 3.2083}$
}

\begin{abstract}
This study aims to analyze the increase in verbal-linguistic intelligence of early childhood through TikTok media at RA Al Husna Krejenengan Probolinggo. The research method used is a qualitative case study type. To get an idea of increasing verbal-linguistic intelligence of early childhood through the use of Tiktok media, researchers conducted interviews with school principals and teachers at RA Al Husna Krejenengan Probolinggo. The results showed that the Tik Tok application, together with appropriate methods and techniques, could be used as an interactive learning medium in increasing early childhood verbal-linguistic intelligence. With its various features and ease of operation, the Tik Tok application can be implemented in dialogue learning between teachers and students.
\end{abstract}

Keywords: linguistic verbal intelligence; early childhood; Tiktok media

\begin{abstract}
Abstrak
Penelitian ini bertujuan untuk menganalisis tentang peningkatan kecerdasan verbal linguistik anak usia dini melalui pemanfaatan media tiktok di RA Al Husna Krejenengan Probolinggo. Metode penelitian yang digunakan adalah kualitatif jenis studi kasus. Guna mendapatkan gambaran tentang peningkatan kecerdasan verbal linguistik anak usia dini melalui pemanfaatan media Tiktok, peneliti melakukan interview terhadap kepala sekolah dan guru di RA Al Husna Krejenengan Probolinggo. Hasil penelitian menunjukkan bahwa aplikasi Tik Tok bersama dengan pengunaan metode dan teknik yang tepat, dapat dimanfaatkan sebagai media pembelajaran yang interaktif dalam meningkatan kecerdasan verbal linguistik anak usia dini. Dengan fiturnya yang beragam dan kemudahan dalam pengoperasian, maka pemanfaatan aplikasi Tik Tok dapat diimplemtasikan dalam pembelajaran dialog antara guru dan peserta didik.
\end{abstract}

KataKunci:kecerdasan verbal linguistik; anak usia dini; media Tiktok

Copyright (c) 2022 Agus Nu'man, et al.

$\triangle$ Corresponding author:

Email Address : maulizasofiya@gmail.com (Paiton, Probolinggo, Indonesia)

Received 15 October 2021, Accepted 23 December 2021, Published 15 January 2022 


\section{INTRODUCTION}

In building an innovative and quality generation, the development must start early informal education forums (Zamroni, 2017; Badrudin et al., 2021; Silviani et al., 2021). Kindergarten is a formal educational forum that has activities to stimulate the growth of children's intellectual potential at the age of 4 to 6 years (Iltiqoiyah, 2020; Rozi et al., 2021). Every child has a different potential for intelligence, including cognitive, language, art, physical motor, religious morals, and social-emotional (Wahid et al., 2021). In other terms, Kindergarten will help parents in developing the potential of children's intelligence optimally, one of which is verbal-linguistic intelligence (Rozalina \& Muryanti, 2020).

The capacity to use the language both orally and in writing is known as verballinguistic intelligence. Children with verbal-linguistic intelligence have excellent listening skills and can talk clearly (Kristina et al., 2020; Zamroni et al., 2021). According to Baum, verbal-linguistic intelligence is the ability to use languages, including mother tongue and foreign language, to express what is in the mind and understand other people (Kamarudin, 2021). Meanwhile, Gardener defines that verbal-linguistic intelligence as the ability to use words effectively, both orally and in writing (R. Dewi et al., 2020)

According to Hanafi, verbal-linguistic intelligence means understanding and manipulating language and words. Every child has intelligence using different strata (Rozi \& Zubaidah, 2021). Children with verbal-linguistic intelligence can be observed according to their ability to read, write, speak, interact, discuss, express opinions, and other verbal and written communication forms (Umiarso \& Hidayati, 2022). But on the other hand, children have sensitivity to sounds, structures, functions in interpreting words (Rozalina \& Muryanti, 2020)

It can be understood that verbal-linguistic intelligence is the language ability possessed by every human being either orally or in writing, and can use words effectively, besides using language competently in listening, writing, reading, and speaking.

Based on the observations and interviews at RA Al Husna, Krejenengan Village, Krejenengan District, Probolinggo Regency, researchers found children who still could not tell something they knew, even though they when the teacher asked some children to tell stories about animals such as cats. And some of the chickens are just silent and smile; there are only one of the many children who can describe the characteristics of these animals. In addition, researchers received information from teacher RA Al Husna that children still need encouragement and stimulus to tell stories. In addition, the use of teaching methods by teachers or parents who are not varied.

A teacher should have effective learning methods and media to overcome the existence of a problem (Wahyudin et al., 2021; Aryani et al., 2021). Social media has become a necessity of life for many people. One of them is among children who are increasingly following the developing times, and children are also tracking an era where social media is becoming a trend (Alfina \& Anwar, 2020). One of the most popular applications among children is TikTok. TikTok social media is media in the form of audiovisual; this media is a social media that can be seen and heard (Fitriana et al., 2021).

Using TikTok is not complicated because only using a smartphone makes videos on TikTok fast and easy. Tik Tok users express themselves plus the existing filters. In addition to learning media to express themselves, children also convince themselves to manage the TikTok application to produce the desired video (Pratiwi et al., 2021).

It is undeniable that children often play with their smartphones to access social media rather than playing and interacting with their environment (Baharun, Muali, et al., 2021). Of the many existing social media, Tik Tok is a new social media that provides a place for its users to express themselves through video content (Savitri \& Ardi, 2021; Sa'ad \& Istifa, 2020). Not a few children also join using this social media. Children's TikTok social media can also imitate dances, sing gymnastics, and so on without external coercion. Children find TikTok 
very fun with various videos and various music. This will increase students' verbal-linguistic intelligence.

Many studies on increasing verbal-linguistic intelligence have been carried out by researchers (Fitriana et al., 2021); for the 2020/2021 academic year, the usage of social media Tik Tok is an effective technique (substantial effect) on Kinesthetic Intelligence in the Age Group 5-6 Years in TK Nusantara Sumberbening, Bringin District, Ngawi Regency.

Then in the second study (Kamarudin 2021), the results show that using singing activities can improve verbal-linguistic intelligence in early childhood, especially for Kindergarten B Kemala Bhayangkari children in Ternate City. This is proven in the first cycle with a weight of 2.3 or $59 \%$ and the second cycle with a weight of 3.2 or $82 \%$, thus an increase of $23 \%$ from the agreement, which only determines an increase of $20 \%$, the final result has exceeded the standard of achievement, namely $75 \%$ so that it can be said that it is already at the Consistent stage. Then in the third study (Kristina et al., 2020), The results showed that designing and developing a rotating wheel media is a solution to facilitate the verballinguistic intelligence of children in group B. This study used the Design-Based Research (DBR) method using a qualitative approach. . The product is designed using the primary materials, namely plywood, wood, flannel, and impraboard. Data collection is by interview and expert validation. Overall, the product is declared suitable for use as a learning medium to facilitate verbal-linguistic intelligence of children aged 5-6 years. Then in the fourth study (Rozalina \& Muryanti, 2020), the results showed that storytelling had a positive effect on developing children's verbal-linguistic intelligence and provided opportunities for children to be active in recognizing and understanding new vocabulary, understanding the plot of a story, processing words to be meaningful, and skilled in speaking. The form of activities carried out in storytelling is in the form of activities that have been seen, close to the world of children, and based on technology.

Then in the fifth study (R. Dewi et al., 2020), The results showed that the implementation of the preparation center in developing verbal-linguistic intelligence at RA Al-Falah was carried out in 3 stages, namely: first, planning, namely educators making learning plans such as Promes, RPPM, RPPH. Second, the implementation includes four steps: the footing of the playing environment, the footing before playing, the base when playing, and the floor after playing. Third, assessment or evaluation. This study shows that verbal-linguistic abilities in RA Al-Falah are developing well; this can be seen from 20 children, 13 of whom have been able to master verbal-linguistic abilities.

Increasing verbal-linguistic intelligence of early childhood through the use of TikTok media at RA Al Husna Krejenengan is expected to be more effective in learning, both from the pattern of delivery that is short and clear and the content delivered is also equipped with audiovisuals that reinforce the material produced. So that the material presented provides its attraction for students.

Some of these researchers explained the importance of innovation to create an atmosphere and effective learning process for students, learning innovations that must be carried out by RA Al Husna Krejenengan, namely increasing verbal-linguistic intelligence for early childhood through the use of TikTok media, so that it can foster student learning enthusiasm in all fields. Aspects of development include elements of cognitive development. Besides that, it can also improve the ability to read, write, speak, interact, discuss, express opinions, and all other forms of verbal and written communication.

Starting from the various explanations above, the researchers tried to apply to learn using Tik Tok media so that the material presented by the teacher was accessible for students to understand and understand. This research aims to analyze and understand how to increase verbal-linguistic intelligence of early childhood through TikTok media at RA Al Husna Krejenengan, Krejingan, Probolinggo. 


\section{METHODOLOGY}

This research uses a qualitative case study approach to get an overview of increasing verbal-linguistic intelligence in early childhood through TikTok media. The research location is at RA Al Husna Krejenengan, precisely on Jalan KH Muh Khazin, Dawuhan Village, Krejingan District, Probolinggo Regency, which is under the auspices of the Al Husna Krejenengan Foundation. In collecting data, the authors used the method of observation, interviews with the principal and the teacher council at RA Al Husna Krejenengan, Probolinggo. Researchers observed the activities of teachers and students in the use of TikTok media as learning media. Other data to corroborate the results are taken from documents supporting and strengthening the research. Some of these data, then analyzed in stages, starting with the presentation of all existing data, then continued with data reduction concerning the research theme raised, and ended with concluding a finding in this study.

\section{RESULTS AND DISCUSSION}

The results showed that; increasing verbal-linguistic intelligence of early childhood through the use of Tiktok media at RA Al Husna Krejenengan, Krejingan, Probolinggo as follows;

\section{Student Learning Problems}

A person with high language intelligence can show an appropriate mastery of the language. These people can tell stories, debate, discuss, interpret and interpret, submit reports, carry out various speaking and writing tasks, and easily influence others through their words.

The head of RA Al Husna Ummi Kulsum (2021) said that children still cannot tell stories about lesson themes such as animal themes, the environment, and others. Meanwhile, according to Ernawati Shalihah (2021), one of the teachers of RA Al Husna explained that there is still communication and interaction between teachers and students is not well established, and even this will affect communication between children and children so that children will look silent and not have the ability to speak. Similarly, Anis Sulaihah as the teacher of RA Al Husna, explained that many children were found unable to communicate well wherein conveying their wishes to the teacher they were still nervous and stammered like when a child asked the teacher to open his drinking cup.

Speaking skills are one of the developments that must be developed in early childhood as a communication tool and a means to express what is felt. In line with the above, in developing one's language, one has specific goals, including; First, so that children can communicate well in oral and written form. Second, the ability to convince others with the language they have. Third, memorizing information, explaining things well to others, and power.

The teacher should assume the role of giving knowledge to children. Besides that, the teacher is also a friendly facilitator and has a high interest in children's learning.

\section{Providing Material}

According to Ummi Kulsum (2021), the Tik Tok application can be an effective learning medium. First, the Tik Tok Application meets the learning needs of students. Both Tik Tok applications attract students' interest because of their novelty and have many features implemented into learning. Meanwhile, according to Anis Sulaihah (2021), an example of using Tik Tok media in education and essential competencies is retelling the contents of narrative texts. First, the teacher gives a narrative text to be observed. After that, students were asked to change the text into a conversational dialogue. The dialogues made are then recorded and practiced through the duet feature provided by Tik Tok. Ernawati Shalihah (2021) explained that the application of TikTok in learning language skills could be applied in many Basic Competencies. Roleplaying skills, for example, in this basic 
competency, emphasize students' suprasegmental aspects in acting out a dialogue between students and teachers. Teachers can use the duet or collaboration feature to create a conversation/dialogue.

The Tik Tok application and appropriate methods and techniques can be used as an interactive learning medium for early childhood learning. The TikTok application can improve students' verbal-linguistic intelligence with its various features and ease of operation. Improving Verbal-Linguistic skills is very important to be trained as a provision for children to communicate well in their environment and use them until they grow up.

\section{Teacher and Parents Collaboration}

In the online learning process using the Tiktok application, the teacher is the leading actor who plans, directs, and carries out this activity. Teachers have the same demands even though learning is done online, namely teaching, guiding, and fostering students.

According to Ummi Kulsum (2021), the teacher sends a video with the Tiktok Application to the Student Guardian Group, whose members are all guardians and teachers; the video will be delivered to his son containing the subject matter such as animal themes and others. Meanwhile, according to Ernawati Shalihah (2021), the teacher sends subject matter according to the schedule that has been distributed in the parent group via TikTok videos, as for the theme according to a predetermined schedule, such as the Fruits lesson theme, in the video we explain and then give the task is for the child to re-explain the article in the form of a video which is then sent to the parent group. We download, correct, and comment on the video. According to Anis Sulaihah (2021), the teacher sends a video to the parent group according to the lesson's theme; in the video sent by the teacher, there is an explanation of the learning theme, such as the theme of body parts. At the end of the video, the teacher explains the tasks that must be fulfilled by the participants themselves, namely re-explaining the music that has been conveyed by the teacher using a Tiktok video and then sending it to the student guardian group, while the teacher comments on the students' video results. Lailatul Fitriyah(2021), as the student's guardian, explained that With the parent group, we always download videos sent by our child's teachers, the contents of which are subject matter. At the end of the video, the teacher asks students to re-explain the material presented by the teacher, and then we send the video with the Tiktok application to the parent group. Not only sending without a response but the teacher commenting on the video results of the assignments given.

In the online learning process using the Tiktok application, the teacher gives examples of explanations about learning themes such as the Animal theme or the environment using the Tiktok application. Students whose parents accompany are asked to explain or mention various animals according to the article conveyed by the teacher through the Tiktok application. Then students whose parents attend can upload the background song media features on the Tik Tok application. Votes are uploaded using the correct expression; then, the master sends the results to the homeroom group. Then the teacher can evaluate the student guardian group. Learners can use the duet or collaboration feature to create a conversation/dialogue.

Thus, the Tik Tok application can be a practical learning medium. First, the Tik Tok Application meets the learning needs of students. Both Tik Tok applications attract students' interest because of their novelty and have many features implemented into learning.

\section{Teacher and Parent Assistance}

According to the head of RA Al Husna Ummi Kulsum (2021), the school continues to strive so that learning reaches the children, of course, with a scheme that is not burdensome. We empower parents with practical and straightforward digital parenting tips to support their child's digital activities in navigating TikTok safely. Meanwhile, according to Anis Sulaihah (2021) that, while studying from home, teachers do not transfer the burden of 
teaching to parents. We understand that many parents do not have an academic teaching background at home. Of course, we prepare a strategy that does not burden parents. According to Ernawati Salihah (2021), while studying at home, the teacher also does not give a lot of workloads; the most important thing is that all students can achieve that competence. The most important thing is the sense of learning remains even at home. So we continue to present a purpose of learning at home in a fun way and not give too much workload. Lailatul Fitriyah (2021), as the student's guardian, explained that parents have the function of accompanying children to study at home. Parents who replace the role of the teacher as a companion. Namely as a companion in shaping the character of children.

It is understood that children under the age of eight still depend on older siblings or parents to do online learning; because they do not yet fully have the ability to operate digital devices, they need to be helped to connect in the online learning process. The need for digital media during the pandemic is significant for all informants' families. Parents provide each child with their digital device for learning purposes. Even though they come from a middle economic background, parents try to give a simple smartphone so that their children can still take part in online learning.

\section{Discussion}

Child development does not happen instantly; children develop like seeds that grow until they become trees. Children's abilities will appear along with the stages of development, and even then, it requires proper stimulation (Rozi, 2021). Teachers are expected to be able to create a meaningful and quality education. However, today's education is unfortunate because early Childhood Education (PAUD) institutions still target students to master reading, writing, and counting (listing). Early childhood is a period where all aspects are stimulated through play activities, where calistung activities are only an introduction, not a necessity which has been explained in Ministerial Regulation Number 58 of 2009 concerning aspects of child development, one of which is about verbal linguistics (R. Dewi et al., 2020)

Ruiyat explained that speaking skills must be developed in early childhood as a communication tool to express what they feel (Rozalina \& Muryanti, 2020). In line with the above, in developing one's language, one has specific goals, including; First, so that children can communicate well in oral and written form. Second, the ability to convince others with the language they have. Third, memorizing information, explaining things well to others, and power. Learning given to early childhood or PAUD students should be delivered in oral/verbal form.

Verbal-linguistic intelligence, according to Gardner, is the capacity to utilize words effectively both orally and in writing. Sensitivity to the meaning of words, word order, tone, rhythm, and intonation of spoken words are all part of this intelligence. This involves the ability to recognize the power of words in altering moods and communicating information (Nofita Anggraini et al., 2020). Children who are intelligent in linguistics may have mastered reading and writing.

Verbal Linguistic Intelligence Indicators for Early Childhood. Linguistic intelligence emerges from the following forms and activities; 1). Children like to communicate with people around them, 2). children love to tell stories, 3). children easily remember the names of friends and family, 4). children like books and spell faster than children his age, 5). the child is easy to pronounce the words, 6). children like and pay attention to stories or reading stories from educators, 7). children have more vocabulary than children their age, 8). children want to imitate their writings and show achievement above their peers, 9). children like to read the report, 10). children enjoy linguistic games (N. luh K. M. Dewi et al., 2017).

An educator must know the purpose of developing verbal-linguistic intelligence. This will be a reference to provide a lesson to help children build their verbal-linguistic intelligence according to their goals. The goals of developing verbal-linguistic intelligence, according to Sujiono include 1) So that children can communicate both orally and in writing well 2) Have 
language skills to convince others 3) Able to remember and memorize information 4) Able to provide explanations 5) Able to discuss language itself (Kristina et al., 2020).

Meanwhile, according to Sujiono, tips for developing verbal-linguistic intelligence in early childhood can be done in the following ways: 1) Invite children to talk; 2) Read stories; 3) Playing letters; 4) Stringing the story; 5) Discuss or converse; 6) Roleplay; 7) Playing children's songs (Kristina et al., 2020).

Learning media is an integral part of the learning system that cannot be separated (Baharun et al., 2021). The teaching and learning process is impossible; it requires one medium to deliver teaching materials (Babuta \& Rahmat, 2019; Farisi \& Wafi, 2021). According to I Wayan Santyasa, the learning process has five communication components: teachers (communicators), learning materials, learning media, students (communicants), and learning objectives. On the other hand, instructional materials are materials or teaching materials that are methodically organized and used by teachers and students in the learning process (Aji, 2020).

Teachers in using media effectively are looking for, finding, and selecting media that meet children's learning needs, attract children's interests, develop maturity and experience, and the unique characteristics in their study groups (Munif et al., 2021). These characteristics include the child's maturity, background experience, and mental conditions related to his developmental age.

The representation of the message conveyed by the teacher should also be considered in the selection of media. There are at least three functions that move together in the existence of the media (Hambali et al., 2021). The first is the stimulation function that creates interest in learning and knowing more about everything in the media. Second, the mediation function is an intermediary between teachers and students. In this case, the media bridges the communication between teachers and students. The three information functions display the explanation that the teacher wants to convey(Aji, 2020). With the presence of media, students can capture the teacher's information or answers they need or want to get. As one of the impacts of covid-19, distance learning has unconsciously changed the concepts, methods, and designs of knowledge already taking place (Puspitasari, 2021; Rozi, Ramdlani, et al., 2021). Before the learning pandemic took place conventionally, which was teacher-centered, educators had to be innovative in designing student-centered learning (Rozi \& Lana, 2021).

The Tik Tok application can be used as a suitable learning medium. First, the Tik Tok Application meets the learning needs of students. Both Tik Tok applications attract students' interest because of their novelty and have many features implemented into learning. And finally, the Tik Tok application is equivalent to the development of maturity and experience and the characteristics of students. According to Ernawati Salihah (2021) at RA Al Husna Krejenengan, the TikTok application in learning language skills can be applied in many Basic Competencies. Roleplaying skills, for example, in this basic competency, emphasize students' suprasegmental aspects in acting out a dialogue between students and teachers. Teachers can use the duet or collaboration feature to create a conversation/dialogue. Anis Sulaihah (2021), delivering examples of the use of Tik Tok media in learning and essential competencies in retelling the contents of narrative texts. First, the teacher gives a narrative text to be observed. After that, students were asked to change the text into a conversational dialogue. The dialogues made are then recorded and practiced through the duet feature provided by Tik Tok.

The Tik Tok application and appropriate methods and techniques can be used as an interactive learning medium for early childhood learning. With its various features and ease of operation, the Tik Tok application can improve students' verbal-linguistic intelligence.

\section{CONCLUSION}

Teachers at RA Al Husna Krejenengan make innovations and creations to make their learning exciting and fun for early childhood. The Tik Tok application and appropriate 
methods and techniques can be used as an interactive learning medium in improving early childhood linguistic verbal intelligence. With its various features and ease of operation, the Tik Tok application can be implemented in dialogue learning between teachers and students.

\section{AKNOWLEDGEMENT}

The researcher would like to thank all parties who have assisted in completing this research, especially to all leaders and teachers at RA Al Husna Krejengan, who have taken the time to provide information to researchers related to various needs and information they wish to obtain. The researcher also thanks the Obsession Journal editor-in-chief, which helped researchers publish this article correctly.

\section{REFERENCES}

Alfina, A., \& Anwar, R. N. (2020). Manajemen Sekolah Ramah Anak Paud Inklusi. Al-Tanzim: Jurnal Manajemen Pendidikan Islam, 4(1), 36-47. https://doi.org/10.33650/altanzim.v4i1.975

Aryani, E., Hasanah, A. U., \& Putra, H. D. (2021). Effect of Head Management Competence on Teacher Performance in SMA Nusantara Plus. Al-Tanzim: Jurnal Manajemen Pendidikan Islam, 5(2), 105-114. https:// doi.org/10.33650/al-tanzim.v5i2.2177

Babuta, A. I., \& Rahmat, A. (2019). Peningkatan Kompetensi Pedagodik Guru melalui Pelaksanaan Supervisi Klinis dengan Teknik Kelompok. Al-Tanzim: Jurnal Manajemen Pendidikan Islam, 3(1), 1-28. https:// doi.org/10.33650/al-tanzim.v3i1.496

Badrudin, Gustini, N., \& Amirullah, C. I. (2021). Correlation of Financing Management Towards The Quality of Education in Madrasah Diniyah Takmiliyah Awaliyah in Bandung District. Al-Tanzim: Jurnal Manajemen Pendidikan Islam, 5(2), 96-104. https:// doi.org/10.33650/al-tanzim.v5i2.2163

Baharun, H., Muali, C., Bali, M. M. E. I., Rozi, F., Rodiah, L. N., Munawaroh, Z., \& Aminah, S. (2021). Learning Strategies for Mobile-Assisted Seamless Learning: A Students' Initial Perceptions. Proceedings of the First International Conference on Science, Technology, Engineering and Industrial Revolution (ICSTEIR 2020), 536(Icsteir 2020), 557-560. https://doi.org/10.2991/assehr.k.210312.089

Baharun, H., Rozi, F., Sholihin, M. W., Faisol, M., Marsida, A., Abdullah, D., Junita, N., Candrasari, R., Fitri, D., Ita, C., Palangkaraya, I., \& Tengah, K. (2021). Learning Effectiveness Improvement Through Mobile Learning. Turkish Online Journal of Qualitative Inquiry, 12(4), 1661-1665.

Dewi, N. luh K. M., Putra, S., \& Suniasih, N. W. (2017). Pengaruh Penerapan Metode Bernyanyi Terhadap Kecerdasan Verbal Linguistik Pada Anak Kelompok B1 Tk Kumara Bhuana Peguyangan Denpasar Utara. E-Journal Pendidikan Anak Usia Dini Universitas Pendidikan Ganesha, 5(2), 137-146.

Dewi, R., Wahyono, I., \& Putri, E. I. E. (2020). Implementasi Metode Sentra Persiapan Dalam Mengembangkan Kecerdasan Verbal Linguistik Anak Usia Dini. TARBIYATUNA: Kajian Pendidikan Islam, 4(1), 95-110. https:// doi.org/10.29062/tarbiyatuna.v4i1.298

Farisi, Y. Al, \& Wafi, A. (2021). Peningkatan Kinerja Guru Melalui Penguatan Kecerdasan Spiritual Di Sekolah. Managere: Indonesian Journal of Educational, 3(1), 85-95. https://doi.org/10.52627/ijeam.v3i1.126

Fitriana, A. A., Azizah, E. N., \& Tanto, O. D. (2021). Pengaruh Media Sosial Tik Tok Terhadap Kecerdasan Kinestetik Anak Usia Dini. JCE (Journal of Childhood Education), 5(1), 147158.

Hambali, H., Rozi, F., \& Farida, N. (2021). Pengelolaan Pembelajaran Ilmu Tajwid Melalui Media Audio Visual. NATURALISTIC: Jurnal Kajian Penelitian Pendidikan Dan Pembelajaran, 5(2), 872-881. https:// doi.org/10.35568/naturalistic.v5i2.1180

Iltiqoiyah, L. (2020). Manajemen Pembelajaran melalui Pendekatan BCCT dalam Meningkatkan Multiple intelligences Anak. Jurnal Obsesi : Jurnal Pendidikan Anak Usia Dini, 5(2), 13681381. https://doi.org/10.31004/obsesi.v5i2.781 
Kamarudin, H. (2021). Peningkatan Kecerdasan Verbal Linguistik Melalui Kegiatan Bernyanyi.

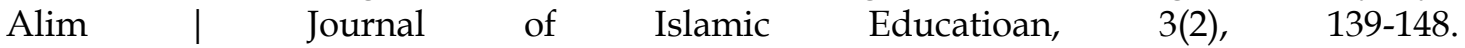
https://doi.org/10.51275/alim.v3i2.209

Kristina, T., Elena, \& Rahman, T. (2020). Desain Media Roda Putar Untuk Memfasilitasi Kecerdasan Verbal Linguistik Anak Pada Kelompok B. Jurnal PAUD Agapedia, 4(2), 314-323.

Munif, M., Rozi, F., Yusrohlana, S., \& Jadid, U. N. (2021). Strategi guru dalam membentuk karakter siswa melalui nilai-nilai kejujuran. Fondatia : Jurnal Pendidikan Dasar, 5(September), 163179. https://doi.org/10.36088/fondatia.v5i2.1409

Nofita Anggraini, Susilastri, D., \& Sudarmanto, B. A. (2020). Permainan "Pohon Kata": Sarana Peningkatan Kecerdasan Verbal Linguistik Anak Usia Dini. Prosiding Seminar Nasional Pendidikan Program Pascasarjana Universitas Pgri Palembang, 3, 940-949.

Pratiwi, D. I., Huda, S. T., \& Kurniawan, D. A. (2021). An Exploratory Study of English Teachers : The Use of Social Media for Teaching English on Distance Learning. 5(January 2020), 361372.

Puspitasari, A. C. D. D. (2021). Aplikasi Tiktok Sebagai Media Pembelajaran Jarak Jauh Pada Mahasiswa Universitas Indraprasta PGRI. Jurnal Educatio, 7(3), 1127-1134.

Rozalina, F. A., \& Muryanti, E. (2020). Mendongeng dengan Power Point dalam Mengembangkan Kecerdasan Verbal Linguistic Anak Usia Dini. Jurnal Pendidikan Tambusai, 4(2), 11821188. https://doi.org/10.29062/tarbiyatuna.v4i1.298

Rozi, F. (2021). Implementation of Overcoming Introverted Children. 13(2). https://doi.org/10.35445/alishlah.v13i2.629

Rozi, F., \& Lana, I. F. (2021). Implementasi Pembelajaran Jarak Jauh (PPJ) dalam Meningkatkan

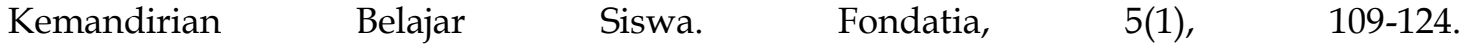
https://doi.org/10.36088/fondatia.v5i1.1108

Rozi, F., \& Zubaidah. (2021). Penerapan Media Gambar Berseri dalam Meningkatkan Bahasa Ekspresif Anak Usia Dini. Murobbi; Jurnal Ilmu Pendidikan, 5(2), 257-272.

Rozi, F., Mubarak, A. F., \& Humaidah. (2021). Penggunaan Media Permainan Bola Angka Terhadap Kemampuan Mengenalkan Konsep Bilangan 1-10 pada Anak. 10(2), 266-277.

Rozi, F., Ramdlani, M., Najah, F., Azizah, N., Niswa, H., Abdillah, M., \& Rozi, F. (2021). Distance Learning and Independent Learning of Students in Higher Education. Journal of Physics: Conference Series, 1899(1). https:// doi.org/10.1088/1742-6596/1899/1/012177

Sa'ad, M., \& Istifa, F. A. (2020). Simulakra Bahasa Agama Da'i Milenial di Media "TikTok." Jurnal Komunikasi Islam, 10(2), 235-255. https:// doi.org/10.15642/jki.2020.10.2.235-255

Savitri, D., \& Ardi, H. (2021). Analysis of Students ' Speaking Ability in Video Project at STKIP $\begin{array}{llll}\text { Muhammadiyah } \quad \text { Muara } & \text { Bungo. }\end{array}$ https://doi.org/10.2991/assehr.k.210325.009

Silviani, S., Maarif, M. A., \& Wibowo, A. (2021). Knowledge Sharing Management: Strategy for Improving the Quality of Human Resources. Al-Tanzim: Jurnal Manajemen Pendidikan Islam, 5(1), 129-139. https:// doi.org/10.33650/al-tanzim.v5i1.1831

Umiarso, \& Hidayati, N. (2022). Improving Children â€TM s Cognitive Intelligence Through Literacy Management. Jurnal Obsesi: Jurnal Pendidikan Anak Usia Dini, 6(3), 1588-1598.

Wahid, A. H., Rozi, F., Baharun, H., Hidayati, W., \& Bon, A. T. (2021). Information Technology in the Development of Language Aspects of Early Childhood.

Wahyudin, U. R., Winara, D., \& Permana, H. (2021). Teacher Professionalism Improvement Management: Study of Principal Leadership at SMA Al-Ittihad Karang Tengah Cianjur. AlTanzim: Jurnal Manajemen Pendidikan Islam, 5(2), 115-124. https://doi.org/10.33650/al-tanzim.v5i2.2222

Zamroni, Amir, \& Saleha, L. (2021). Pengelolaan APE Berbahan Limbah untuk Meningkatkan Kecerdasan Kognitif Anak. Jurnal Obsesi: Jurnal Pendidikan Anak Usia Dini, 5(2), 13821395. https://doi.org/10.31004/obsesi.v5i2.763

Zamroni. (2017). Manajemen Mutu Pendidikan: Ikhtiar dalam Meningkatkan Mutu Pendidikan Madrasah melalui Pendekatan Balanced Scorecard (1st ed.). Akademia Pustaka. https://doi.org/10.30659/jpai.1.1.41-56 